Bhatter College Journal of Multidisciplinary Studies

Approved by the UGC (Serial No. 629, Subjects: Education, Broad category: Social Sciences)

ISSN 2249-3301, Vol. VII, Number 1, 2017

Article url: www.bcjms.bhattercollege.ac.in/v7/n1/mc-en-v7-01-03.pdf

Article DOI: 10.25274/bcjms.v7n1.mc-en-v7-01-03

\title{
Customer Perception and Satisfaction towards Basmati Rice in Jammu Region of J\&K State
}

\author{
Naveed Hamid ${ }^{1,}$ Kushum saini $^{2}$, and Jyoti Kachroo ${ }^{1}$ \\ ${ }^{1}$ Division of Agricultural Economic and Agri Business Management SKUAST-Jammu \\ ${ }^{2}$ ScholarDivision of Agricultural Economic and Agri Business Management SKUAST-Jammu
}

Correspondence address:

Mr. Naveed Hamid

Division of Agricultural Economics and ABM, SKUAST-Jammu.Email: bhatnaveedbhat@gmail.com

\begin{abstract}
Agriculture is an important part of India's economy and at present it is among the top two farm producers in the world. This sector provides approximately 68 percent of the total number of jobs available in India and contributes around 14.2 percent to the GDP. India and China produce about 250,000 million tons of rice between them..India is the leading exporter of the Basmati Rice to the global market as the country has exported 37, 02,260.12 MT of Basmati Rice to the world for the worth of 27,597.87 crores during the year 2014-15. The Jammu and Kashmir is considered to be favorable state of production of Basmati rice with its pleasant climatic conditions. In Jammu and Kashmir the Basmati is confined at the areas of R.S. Pura, Samba and Kathua. The present study was carried out in district Jammu of Jammu and Kashmir state with the aim of understanding the Consumer Satisfaction and Perception level towards Sarveshwar Foods Limited. The present study uses primary data (150 Sarveshwar Basmati Consumers) and secondary data for fulfilling the objectives of the study. The study adopts descriptive, regression and Cross Tab (Chi Square Test) for analysis purposes. The results of the study revealed that the customers are satisfied with the Sarveshwar products in terms of quality and packaging respectively and customer's perception towards the Sarveshwar rice is fair in terms of the factors related to perception level. The study also depicts that there existed no relation or impact over the satisfaction and perception level by the demographic factors as the result showed that the tabular result of these factors are greater than the expected value, hence rejection of the Null hypotheses (hypothetical statements).
\end{abstract}

Keywords: Perception, Satisfaction, Cross tab, Significance level, Null hypotheses

\section{Introduction}

As the rice industry is gaining a lot of market share in India, in the background of changing food pattern, understanding customers perceptions, building relationship and retaining customers has been identified as major source of competitive advantage. Businesses around the world are becoming increasingly competitive day by day. Therefore in order to generate more customers and retain existing ones, it is important to know the consumer perception and satisfaction level towards that product.

In today's globalizing economy competition is getting more and more fierce. That means it becomes more difficult for products and services to differentiate themselves from other offerings

Editor-in-Chief: Dr. Pabitra Kumar Mishra. Published by Bhatter College, Dantan. NAAC accredited A grade college. P.O. Dantan, Paschim Medinipur, West Bengal, India. www.bhattercollege.ac.in. (C) Bhatter College, Dantan 
than ever before. Not only is the number of competitive offerings rising due to globalization of production, sourcing, logistics and access to information. Many products and services face new competition from substitutes and from completely new offerings or bundles from industry outsiders. Since product differences are closed at an increasing speed and many companies try to win the battle for customers by price reductions, products and services tend to become commodities. In this situation the development of a strong relationship between customers and a company could likely prove to be a significant opportunity for competitive advantage. This relationship is no longer based on features like price and quality alone. Today it is more the perceived experience a customer makes in his various interactions with a company (e.g. how fast, easy, efficient and reliable the process is) that can make or break the relationship. So this study focused on consumer perception and satisfaction scenario.

It acts as a key performance indicator within business and is often part of a Balanced Scorecard. In a competitive marketplace where businesses compete for customers, customer satisfaction is seen as a key differentiator and increasingly has become a key element of business strategy."Within organizations, customer satisfaction ratings can have powerful effects. They focus employees on the importance of fulfilling customers' expectations. Furthermore, when these ratings dip, they warn of problems that can affect sales and profitability. These metrics quantify an important dynamic. When a brand has loyal customers, it gains positive word-of-mouth marketing, which is both free and highly effective. Therefore, it is essential for businesses to effectively manage customer satisfaction. To be able do this, firms need reliable and representative measures of satisfaction. (Beerli et al. 2004)

\section{OBJECTIVES OF THE STUDY}

1. To determine the influencing factors responsible for customer perception towards Sarveshwar Basmati Rice.

2. To determine the level of satisfaction for Sarveshwar Basmati Rice.

\section{RESEARCH METHODOLOGY}

The study was based on primary and secondary sources of information. The research was conducted with the help of schedule and after collection of the required data from the company, it has been analysed by using the Pie Chart, Bar chart and percentage methods.

\section{RESULTS AND DISCUSSION}

The Table 1 represents the gender profile of the respondents of the study area. It is clear from the Fig 5.1that out of 150 respondents, 116 (77 per cent) were male and 34 (23 per cent) were female.

Table 2 represents the age of the respondents of the sample area. It is clear from the Fig 2 that 33 respondents ( 22 per cent) were in the age group of 18 to 29 years, 69respondents (46 per cent) age lies in 30 to 49 years and 48 respondents ( 32 per cent) age lies in 50 to 69 years.

Table 3 represents the education of the respondents. It is clear from the Fig 3 that 14 respondent (9.33 percent) education level fall under category was up to of primary school, 23 respondent (15.33 percent) education level matric, 46 respondent (30.67 percent) education level fall under category high education, 38 respondent (25.33 percent) education level was graduation, 20 
respondent (13.34 percent) education level was post-graduation and 9 respondents (6 percent) had Ph.D.

Table 4 shows that majorly 68 (45.33 percent) respondents has 3 to 4 members in their family, follow by 36 ( 24 percent) respondents had 1 to 2 members in their family, 31 (21 percent) respondents had 5 to 6 members in their family and 15 respondents $(10$ percent) belonged to 7 to 8 family size.

Table 5 highlighted that majorly 119 (79.33 percent) respondents was married, 25 (16.67per cent) respondents was single, 1 (0.67 per cent) respondents was divorces and 5 (3.33 per cent) respondents was widowed.

It has been observed from frequency table 6 that108 (72 percent) respondents were belonging to urban area, followed by 27 (18 percent) respondents belonged to suburban area and 15 (10 percent) respondents were belonged to rural area.

It has been analyzed from table 7 that majority of the respondents i.e. 87 (58 percent) income fall under range of 20,000 to 30,000 earned 20,000 to 30,000, followed by 34 (22.67 percent) respondents earned 10,000 to 20,000, followed by 19 (12.66 percent) respondent earned 30,000 to 40,000 and 10 (6.67per cent) respondents earned below 10,000.

The frequency table 8 revealed that out of 150 respondents majority of the respondents i.e. 94 (62.67 percent) were themselves making their purchasing decisions, by own depends upon 42 (28 percent) respondents concerned others, 9 respondents ( 6 percent) upon their parents and 5 (3.33 per cent) respondents were taking opinion of their son and daughters for making their purchasing decisions.

Table 1: Customer demography

\begin{tabular}{|c|c|c|}
\hline Customer demography & Frequency & Percentage \\
\hline Male & 116 & 77.33 \\
\hline Female & 34 & 22.67 \\
\hline Total & $\mathbf{1 5 0}$ & $\mathbf{1 0 0}$ \\
\hline
\end{tabular}

Source: survey

Table 2: Age of the respondents

\begin{tabular}{|c|c|c|}
\hline Age of the respondents & Frequency & Percentage \\
\hline 18 to 29 year old & 33 & 22 \\
\hline 30 to 49 year old & 69 & 46 \\
\hline 50 to 69 year old & 48 & 32 \\
\hline Total & $\mathbf{1 5 0}$ & $\mathbf{1 0 0}$ \\
\hline
\end{tabular}

Source: survey 
Table 3: Level of education of the respondents

\begin{tabular}{|c|c|c|}
\hline Level of education of the respondents & Frequency & Percentage \\
\hline Primary school & 14 & 9.33 \\
\hline Matric & 23 & 15.33 \\
\hline High education & 46 & 30.67 \\
\hline Graduation & 38 & 25.33 \\
\hline Post-graduation & 20 & 13.34 \\
\hline Ph.D. & 9 & $\mathbf{1 0 0}$ \\
\hline Total & $\mathbf{1 5 0}$ & 6 \\
\hline
\end{tabular}

Source: survey

Table 4: Family size of the respondents

\begin{tabular}{|c|c|c|}
\hline Family size of the respondents & Frequency & Percentage \\
\hline 1 to 2 & 36 & 24 \\
\hline 3 to 4 & 68 & 45.33 \\
\hline 5 to 6 & 31 & 21 \\
\hline 7 to 8 & 15 & 10 \\
\hline Total & $\mathbf{1 5 0}$ & $\mathbf{1 0 0}$ \\
\hline
\end{tabular}

Source: survey

Table 5: Marital status of the respondents

\begin{tabular}{|c|c|c|}
\hline Marital status of the respondents & Frequency & Percentage \\
\hline Single & 25 & 16.67 \\
\hline Married & 119 & 79.33 \\
\hline Divorces & 1 & 0.67 \\
\hline Widowed & 5 & 3.33 \\
\hline Total & $\mathbf{1 5 0}$ & $\mathbf{1 0 0}$ \\
\hline
\end{tabular}


Source: survey

Table 6: Area belongs to respondents

\begin{tabular}{|c|c|c|}
\hline Area belongs to respondents & Frequency & Percentage \\
\hline Urban & 108 & 72 \\
\hline Suburban & 27 & 18 \\
\hline Rural & 15 & 10 \\
\hline Total & $\mathbf{1 5 0}$ & $\mathbf{1 0 0}$ \\
\hline
\end{tabular}

Source: survey

Table 7: Income Level of the respondents

\begin{tabular}{|c|c|c|}
\hline Income Level of the respondents & Frequency & Percentage \\
\hline Below 10,000 & 10 & 6.67 \\
\hline 10,000 to 20,000 & 34 & 22.67 \\
\hline 20,000 to 30,000 & 87 & 12.66 \\
\hline 30,000 to 40,000 & 19 & $\mathbf{1 0 0}$ \\
\hline Total & $\mathbf{1 5 0}$ & 58 \\
\hline
\end{tabular}

Source: survey

Table 8: Family decision makers of the respondents

\begin{tabular}{|c|c|c|}
\hline $\begin{array}{c}\text { Family decision makers of the } \\
\text { respondents }\end{array}$ & Frequency & Percentage \\
\hline Myself & 94 & 62.67 \\
\hline My parents & 9 & 6 \\
\hline My son or daughter & 5 & 3.33 \\
\hline Others & 42 & 28 \\
\hline Total & $\mathbf{1 5 0}$ & $\mathbf{1 0 0}$ \\
\hline
\end{tabular}

Source: survey

Fig 9 and its frequency table 9 highlighted that all the respondents i.e. 150 (100 percent) were consumed Sarveshwar rice taken fron the sample area in Jammu region. 
It has been analyzed from Figure 10 and frequency table 10 that out of 150 respondents majority of respondents i.e. 141 (94 percent) liked Sarveshwar Basmati rice and only 9 respondents (6 percent) were not liked the Sarveshwar Basmati rice.

Figure 11 and its frequency table 11 reflected that majority of the respondents i.e. 134 (89.33 percent) were making monthly purchasing of Sarveshwar rice, while 13 ( 8.67 percent)respondents were purchased Sarveshwar rice on yearly basis and 3 (2 percent) respondents purchased on weekly basis purchased Sarveshwar rice.

Figure 12 and its frequency table 12 highlighted majority of the respondents i.e. $112(82.67$ percent) consumed Sarveshwar XL, followed by 22 (10.67 percent) respondents consuming Sarveshwar unique and 16 (6.66 per cent) respondents were consumed Sarveshwar grand.

Figure 13 and its frequency table 13 highlighted that brand was the major factor that affects 72 (48 percent) respondents, Followed by suggestion from friends and relatives also the main factor that influenced 58 (38.67 percent)respondents, followed by attractive display influenced 13 (8.67 percent)respondents and advertisement influenced 7 (4.66percent) respondents respectively.

Figure 14 and its frequency table 14 showed that hooding is the major factor influencing 112 (74.67 percent) respondents were of the opinion that hooding is the major factor influencing Sarveshwar purchase in sample area followed by newspaper influencing 18 (12 percent) respondents, Banners influencing 13 (8.66 percent) respondents and television influencing 7 (4.67 percent) respondents for Sarveshwar purchase in sample area of Jammu region.

It has been observed from the figure 15 and its frequency table 15 that majority of the respondents i.e. 80 (53.34 per cent) preferred to go to other shop to search for their preferred brand, followed by 56 (37.33 per cent) respondents were switch over to other brand and 14 (9.33 percent) respondents were preferred to postpone their purchase.

Table 9: Sarveshwar rice consumption in sample area

\begin{tabular}{|c|c|c|}
\hline $\begin{array}{c}\text { Sarveshwar rice } \\
\text { consumption }\end{array}$ & Frequency & Percentage \\
\hline Yes & 150 & 100 \\
\hline No & 0 & 0 \\
\hline Total & $\mathbf{1 5 0}$ & $\mathbf{1 0 0}$ \\
\hline
\end{tabular}

Source: survey

Table 10: Response of respondents toward Sarveshwar rice

\begin{tabular}{|c|c|c|}
\hline $\begin{array}{c}\text { Response of respondents } \\
\text { toward Sarveshwar rice }\end{array}$ & Frequency & Percentage \\
\hline Yes & 141 & 94 \\
\hline No & 9 & 6 \\
\hline Total & $\mathbf{1 5 0}$ & $\mathbf{1 0 0}$ \\
\hline
\end{tabular}


Source: survey

Table 11: Purchase pace of Sarveshwar rice in sample area

\begin{tabular}{|c|c|c|}
\hline Purchase pace of Sarveshwar rice & Frequency & Percentage \\
\hline Weekly & 3 & 2.00 \\
\hline Monthly & 134 & 89.33 \\
\hline Yearly & 13 & 8.67 \\
\hline Total & $\mathbf{1 5 0}$ & $\mathbf{1 0 0}$ \\
\hline
\end{tabular}

Source: survey

Table 12: Perception of Sarveshwar rice brands in sample area

\begin{tabular}{|c|c|c|}
\hline Perception of Sarveshwar rice brands & Frequency & Percentage \\
\hline Sarveshwar XL & 112 & 82.67 \\
\hline Sarveshwar unique & 22 & 10.67 \\
\hline Sarveshwar grand & 16 & 6.66 \\
\hline Total & $\mathbf{1 5 0}$ & $\mathbf{1 0 0}$ \\
\hline
\end{tabular}

Source: survey

Table 13: Factor affecting Sarveshwar rice in sample area

\begin{tabular}{|c|c|c|}
\hline Factor affecting Sarveshwar rice & Frequency & Percentage \\
\hline Suggestion from friends and relatives & 58 & 38.67 \\
\hline Attractive display & 13 & 8.67 \\
\hline Brand & 72 & 48.00 \\
\hline Advertisement & 7 & 4.66 \\
\hline Total & $\mathbf{1 5 0}$ & $\mathbf{1 0 0}$ \\
\hline
\end{tabular}

Source: survey

Table 14: Factor influencing Sarveshwar purchase in sample area

\begin{tabular}{|c|c|c|}
\hline Factor influencing Sarveshwar purchase & Frequency & Percentage \\
\hline Television & 7 & 4.67 \\
\hline
\end{tabular}




\begin{tabular}{|c|c|c|}
\hline Newspaper & 18 & 12 \\
\hline Hooding & 112 & 74.67 \\
\hline Banners & 13 & 8.66 \\
\hline Total & $\mathbf{1 5 0}$ & $\mathbf{1 0 0}$ \\
\hline
\end{tabular}

Source: survey

Table 15: Response of respondent at time of non-availability of Sarveshwar rice brand

\begin{tabular}{|c|c|c|}
\hline $\begin{array}{c}\text { Response of respondent at time of non- } \\
\text { availability of Sarveshwar rice brand }\end{array}$ & Frequency & Percentage \\
\hline Postpone your purchase & 14 & 9.33 \\
\hline $\begin{array}{c}\text { Switch over to other brand } \\
\text { Go to other shop to search for your } \\
\text { preferred brand }\end{array}$ & 80 & 37.33 \\
\hline Total & $\mathbf{1 5 0}$ & $\mathbf{1 0 0}$ \\
\hline
\end{tabular}

Source: survey

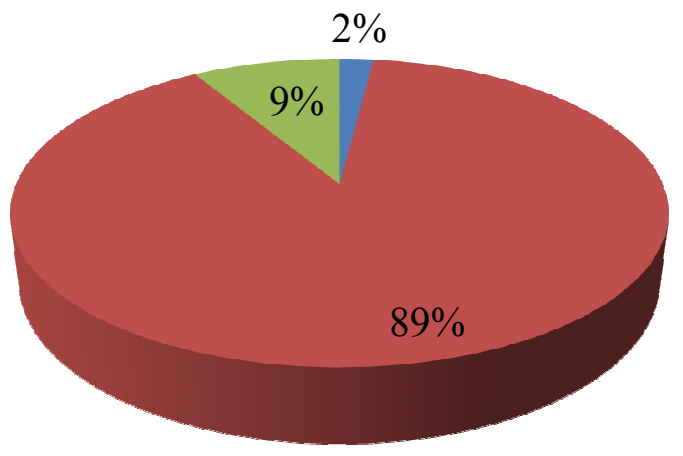

Weekly

Monthly

- Yearly

Fig. 11: Purchase pace of Sarveshwar rice in sample area 


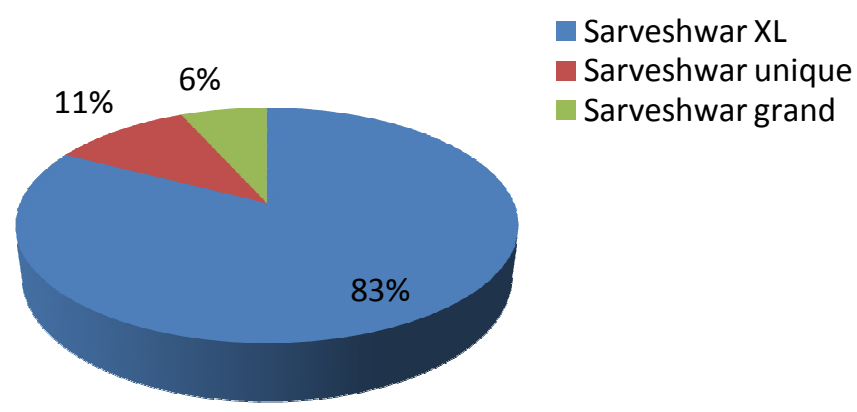

Fig. 12: Perception of Sarveshwar rice brands in sample area

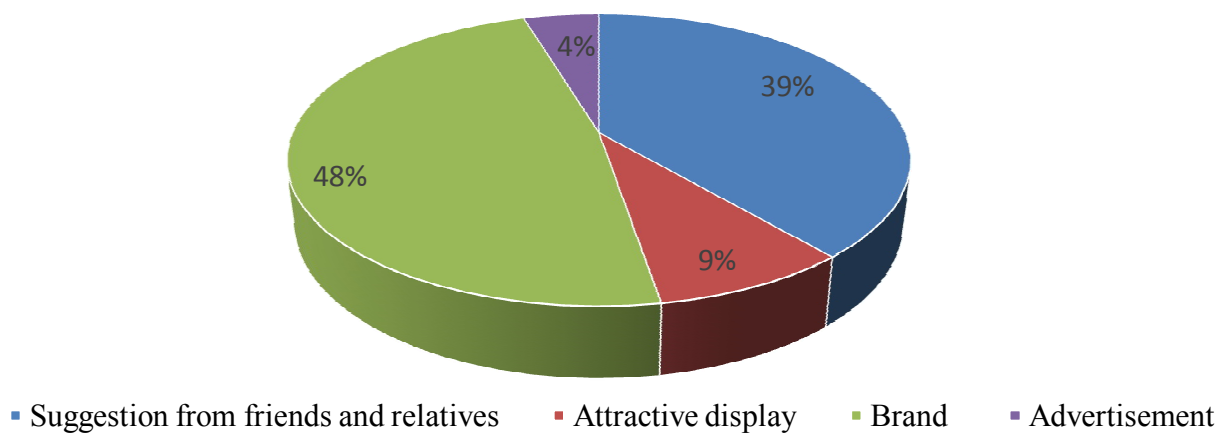

Figure 13: Factor affecting Sarveshwar rice in sample area

It has been observed from the figure 16 and its frequency table 16 that majority of the respondents were not at all consider other brands i.e. 67 (44.67 percent) at the time of competitor, followed by 60 (40 percent) respondents were not sure what they would do at the time of competitors and 23 (15.33 percent) respondents responded that they would preferred to Stop using this brand and buy the new brand at the time of competitor available in the market.

The table 17 depicts that one of the various factors regards perception of respondents towards Sarveshwar basmati rice, respondents depends most upon taste attribute (3.440) followed by availability (3.400) followed by brand (3.220), followed by packaging design (2.820) followed by size of pack (2.727) followed by nutritional value (2.700) and followed by price (2.639) respectively.

Figure 17 and its frequency table 18 highlighted that 105 (70 percent)respondents were liking quality attribute in Sarveshwar rice, followed by 17 respondents (11.33 percent) liking packaging attribute in Sarveshwar rice, 11 respondents (7.34 percent) range attribute in Sarveshwar rice, 8 respondents (5.33 percent) liking prices attribute in Sarveshwar rice, 5 respondents (3.33 percent) liking consistency of quality attribute in Sarveshwar rice and 4 respondents (2.67 percent) liking Length of life attribute in Sarveshwar rice by the respondents time of competitors in the market.

The table 19 depicts that out of the various factors regards importance of performance attributes in sample area. The table reveals that usage experience (4.36) followed by overall quality 
(3.74) followed by first experience (3.39) followed by purchasing experience (3.09) and followed by value (2.68) respectively.

Table 16: Preference of rice brand at the time of competitor

\begin{tabular}{|c|c|c|}
\hline Preference of rice brand at the time of competitor & Frequency & Percentage \\
\hline Stop using this brand and buy the new brand? & 23 & 15.33 \\
\hline No, not at all I may consider & 67 & 44.67 \\
\hline Can't say & 60 & 40 \\
\hline Total & $\mathbf{1 5 0}$ & $\mathbf{1 0 0}$ \\
\hline
\end{tabular}

Source: survey

Table 17: Perception of respondents toward Sarveshwar basmati rice

\begin{tabular}{|c|c|c|c|c|c|c|c|c|}
\hline & Price & Brand & $\begin{array}{l}\text { Availa } \\
\text { bility }\end{array}$ & Taste & $\begin{array}{l}\text { Adverti } \\
\text { sement }\end{array}$ & $\begin{array}{l}\text { Package } \\
\text { Design }\end{array}$ & $\begin{array}{l}\text { Size of } \\
\text { Pack }\end{array}$ & $\begin{array}{l}\text { Nutritional } \\
\text { Value }\end{array}$ \\
\hline Mean & 2.693 & 3.220 & 3.400 & 3.440 & 2.227 & 2.820 & 2.727 & 2.700 \\
\hline Median & 2.000 & 4.000 & 3.000 & 4.000 & 2.000 & 3.000 & 2.000 & 3.000 \\
\hline Mode & 2.000 & 4.000 & 4.000 & 4.000 & 3.000 & 2.000 & 2.000 & 3.000 \\
\hline $\begin{array}{c}\text { Standar } \\
\text { d } \\
\text { Deviatio } \\
\mathrm{n}\end{array}$ & 1.003 & 1.423 & 0.811 & 0.839 & 0.913 & 1.254 & 1.061 & 0.712 \\
\hline $\begin{array}{c}\text { Sample } \\
\text { Varianc } \\
\mathrm{e}\end{array}$ & 1.006 & 2.025 & 0.658 & 0.704 & 0.834 & 1.571 & 1.126 & 0.507 \\
\hline \begin{tabular}{c} 
Count \\
\hline
\end{tabular} & 150 & 150 & 150 & 150 & 150 & 150 & 150 & 150 \\
\hline
\end{tabular}

Source: survey

Table 18 Liking attribute in Sarveshwar rice by the respondents

\begin{tabular}{|c|c|c|}
\hline $\begin{array}{c}\text { Liking attribute in Sarveshwar rice by } \\
\text { the respondents time of competitor }\end{array}$ & Frequency & Percentage \\
\hline Quality of the Sarveshwar rice & 105 & 70 \\
\hline Length of life of Sarveshwar rice & 4 & 2.67 \\
\hline
\end{tabular}




\begin{tabular}{|c|c|c|}
\hline Packaging of Sarveshwar rice & 17 & 11.33 \\
\hline Consistency of quality & 5 & 3.33 \\
\hline Range of Sarveshwar rice & 11 & 7.34 \\
\hline Prices of Sarveshwar rice & 8 & 5.33 \\
\hline Total & $\mathbf{1 5 0}$ & $\mathbf{1 0 0}$ \\
\hline
\end{tabular}

Source: survey

Table 19: Importance of performance attributes in sample area

\begin{tabular}{|c|c|c|c|c|c|}
\hline & $\begin{array}{c}\text { Overall } \\
\text { Quality }\end{array}$ & Value & $\begin{array}{c}\text { Purchasing } \\
\text { Experience }\end{array}$ & $\begin{array}{c}\text { First } \\
\text { Experience }\end{array}$ & $\begin{array}{c}\text { Usage } \\
\text { Experience }\end{array}$ \\
\hline Mean & 3.74 & 2.68 & 3.09 & 3.39 & 4.36 \\
\hline $\begin{array}{c}\text { Standard } \\
\text { Error }\end{array}$ & 0.05 & 0.07 & 0.07 & 0.05 & 0.06 \\
\hline Median & 4.00 & 2.00 & 3.00 & 3.00 & 4.00 \\
\hline Mode & 4.00 & 2.00 & 4.00 & 3.00 & 5.00 \\
\hline $\begin{array}{c}\text { Standard } \\
\text { Deviation }\end{array}$ & 0.61 & 0.85 & 0.91 & 0.35 & 0.73 \\
\hline Count & 150 & 150 & 150 & 150 & 150 \\
\hline
\end{tabular}

Source: survey

\section{CONCLUSION AND RECOMMENDATIONS}

Sarveshwar Brand is leading due to good perception level and response of the customers towards Sarveshwar Basmati Rice. Out of 150 respondents using Sarveshwar Basmati Rice 141 (94 per cent) liked Sarveshwar Basmati Rice. Sarveshwar XL brand is mostly preferred by the customers. The result also revealed that Hooding is the major factor influencing Sarveshwar purchase. Majority of the respondents preferred to go to other shop to search for their preferred brand. The best thing is that majority of the respondents were not at all consider other brands at the time of presence of different competitors, Among all the factor respondents have showed higher response on taste attribute that means taste is the most important factor affecting the customer perception.

It is found that majority of the respondents are satisfied with Sarveshwar Basmati Rice. Among all the factors the respondents has picked quality as the most important factor affecting customer satisfaction. Usage experience is the most important performance attribute in the sample area. The results showed that among the various factors (Taste, Quality, Quantity, Availability, Packaging, Price, Brand image, Advertisement, Aroma, Variety, Offers and discount) the 
Advertisement and Variety showed the insignificant value i.e. $(>0.5)$ which stated that in the sample area, company should try to focus on quality, Advertisement and variety to satisfy the customer at large estate. As per the respondent response Sarveshwar Basmati Rice is a reasonable product regarding value of money and majority of the respondent would like to suggest others to use Sarveshwar Basmati Rice.

\section{RECOMMENDATIONS}

- Company should adopt the strategy to make good relations with customers by satisfying their requirements, understanding their preferences etc.

- There is no customer service centre of the Sarveshwar foods ltd. company has required to have at least one customer service centres to listen customers grievances and take feedbacks about their products.

- Sarveshwar foods ltd. should try to focus on marketing mix efficiently.

- Company should try to make all brands available to the market.

\section{REFERENCES:}

Apoorva, P, 2004. 'Consumer preferences in purchase of ready to eat snacks branded potato chips, Indian Journal of Marketing, 4 (9), 34-38.

Adeolu B. Ayanwale, Taiwo.A and Matthew A. 2005. 'The Influence of advertising on Consumer Brand Preference', Journal of Social Science, 10(1):9-16.

Chih, Wen Hai 2007. The relations among service quality, consumer satisfaction, and loyalty of news websites. Journal of Quality, 14(3):285-299.

Gopi, K., \& Arasu, R. 2012. Consumer preferences towards soft drink products in dharmapuri - a factor analysis evidence. Namex International Journal of Management Research, 2(1):38-47.

Noor F.J and Ramakrishnan Lalitha, 2012. A Study on Consumer's Preference towards Popular FMCG Brands in Rural Market, Global Joumal of Arts \& MgMT, 281-284.

Prema R. 2013. An Empirical Study on Brand Preference towards Edible oil in Rural Areas with Special Reference to Coimbatore District, Indian Journal of Applied Research X 227, 3(3):223-227.

Pathak S.V. \& Tripathi A.P, 2009. Customer Shopping Behaviour among Modern Retail Formats: A Study of Delhi \& NCR, Indian Journal of Marketing, 39:10. 